\title{
ISLAMIC BANKING AND ECONOMIC GROWTH: APPLYING THE CONVENTIONAL HYPOTHESIS
}

\author{
Ahmad Jawad ${ }^{1,2}$ and Klein Christian ${ }^{1}$ \\ ${ }^{1}$ University of Kassel, Faculty of Economics, Department of Corporate Finance, Nora Platiel Strasse 4, \\ D-34127 Kassel, Germany, jawad.azeez@student.uni-kassel.de, jawadahmad@iiu.edu.pk \\ ${ }^{2}$ IIIE, International Islamic University, H-10, Islamabad, Pakistan
}

\begin{abstract}
Growth in Islamic banking has gained lot of interest and attention during last few years. The debate currently shifts from theoretical to empirical framework. The growth in empirical work has given rise to a new concept, which can be called as "Islamic banking development" (IBD). It will be interesting to test nexus between IBD and growth, since literature suggests a positive result for conventional finance and growth. Our study uses a panel of 24 countries for a period of 11 years using annual data (2004-2014) to test conventional hypothesis of supply leading or demand following between IBD and growth. In addition, we also investigate direction of causality in a panel setting between the two. Apart from the topic, this paper differs from existing limited literature, on the basis of dataset used and the estimation procedure to assess the nexus. Our results suggest that IBD affect growth positively. Comprehensive tests suggest the presence of a long run relationship between IBD and growth. Moreover, the direction of causality seems to follow supply leading hypothesis: IBD affects economic growth, and that evidence on a reverse causality was not found. This is true, even when we control for CFD.
\end{abstract}

Keywords: Panel Data, Financial Development, Islamic Banking, Economic Growth. JEL Classification: G10; G21; O16.

Article history:

Received : October 29, 2018

Revised : February 13, 2019

Accepted : February 26, 2019

Available online : March 15, 2019

https://doi.org/10.21098/jimf.v5i1.1047 


\section{INTRODUCTION}

Financial markets, which include commercial banks, stock markets, bond markets and others, play an important role of channeling funds from savers to users, who can use these funds productively. This productive allocation is than believed to affect economic growth (see for example Levine, 2003; Demetriades \& Andrianova, 2004; Demetriades \& Hussein, 1996; Goodhart, 2004). Levine (2003) point out five key functions of a financial system, (i) diversification of risk; (ii) allocation of capital; (iii) monitoring of financed ventures along with capital governance of borrowers; (iv) mobilization and pooling of savings; and (v) facilitating the exchange of goods and services. The better the functions accomplish, the more developed a financial system (or indicating an advance financial system). Hence, a level of financial development could measure how efficiently financial system can perform functions.

The debate on the relation between financial market development and economic growth started in 1973, and since then there were many studies conducted to assess the relation between the two both on the country and panel levels. Most of these studies suggest a positive relation, with the exception of few studies that found no relationship (Levine, 1997; Levine et al., 2000). These studies dealt with, what is called "conventional financial markets", which include conventional banks and stock exchanges. However, there is another system emerging within financial market, which is rapidly making its place in literature and usage. It is known as Islamic financial market. This system is given the name "Islamic" because of the notion that financial laws are governed by the financial teachings of Islamic religion ${ }^{1}$. Much debate has already been in literature about its feasibility, differences, and commonalities with the conventional financial system, but very little literature is available with regard to its contribution towards economic growth.

As previously mentioned, the literature examining the relation between Islamic finance and economic growth is far less than its counterpart in conventional financial development $(\mathrm{CFD})^{2}$. The growing importance and size of Islamic financial market makes it highly relevant to assess its role on economic growth. Islamic banking, a major part of Islamic financial market, has seen a significant amount of development and is growing at a higher pace. The growth rate in Islamic banking for the period, 2009-2013 was recorded to be around 17.6\% (Ernst and Young 2013). It is estimated in the same report that this industry is expected to reach over USD 6.1 trillion by 2020. Among the countries where the presence of Islamic banking are Bahrain, Qatar, Saudi Arabia, UAE, Kuwait, Pakistan, and Saudi Arabia, known as the seven core markets accounted for almost $90 \%$ of the total market. In UAE and Malaysia, the growth of Islamic banks is converging to that of conventional banks, indicating their growing roles in the financial sector of these countries. Twenty-two international participating banks have more than US $\$ 1$ billion in shareholder equity, which gives them a potential position to lead

1. The branch of Shariah dealing with financial laws is known as Fiqh-ul-Muamlat or Law of commercial transactions.

2. As this study will differentiate between Islamic financial development or IBD and main stream financial development, so the later will be written as conventional financial development or CFD. 
the market in their regions. Saudi Arabia, Qatar, and Pakistan have double-digit growth in assets of Islamic banking, experiencing 15\%, 15\% and 10\% respectively (Ernst and Young, 2015). The examining of the link between Islamic banking development (IBD) and economic growth will be interesting in the sense because among available literature there are conflicting views, and such studies are often limited as to the selection of countries or data. Moreover, there are more theoretical studies than the empirical ones ${ }^{3}$.

The current paper is an attempt to supplement in this limited literature by assessing three questions and at the same time improving on previous studies on similar topic. Among the three questions of interest, the first is to analyze if IBD have any impact on economic growth. We will use panel set of 24 countries, contrary to the case of taking only one country or only Organization of Islamic Countries (OIC) as was used in previous research. In addition, we will employ comprehensive panel tests to assess and to establish relationship between the two. These tests have been used to investigate the link between CFD and growth but were never used to assess the relation between IBD and growth as per our information.

A positive answer to the question will take this assessment to next question i.e. whether there exists a long run relation between IBD and growth? For this purpose, we will use more than one test for unit root and co-integration that was not carried out in previous studies related to IBD. The application of these tests will minimize, if not eliminate, the problems of low power associated with the traditional unit root and co-integration tests. On the other hand, pooling will allow reliable tests and/with higher degree of freedom as well as allowing for heterogeneity among countries. The third question takes us to determine the direction of causality between IBD and growth. It will be accomplishing by employing causality test to determine either IBD cause growth or the other way around. The assessment will be stimulating and distinctive, when CFD is accounted in IBD. This type of causality within a similar topic was never analyzed before. The answer to the last question will help establish the supply leading or demand following hypothesis for Islamic banking.

In addition to the questions unique to Islamic banking, 11 years of data will be used, which will not only give more concrete results, but can be helpful in explaining the causality on a more general level. For this purpose, the data will be calculated from the financial statements ${ }^{4}$. In earlier studies the data were taken usually from electronic database that was (and still is) usually imbalanced and had limited Islamic banks. By calculating the data from financial statements directly, the data would be more balanced and updated. In addition, there will be inclusion of more banks that are usually missing in electronic database.

We begin section 2 by summarizing the literature review and providing an argument for Islamic finance. In Section 3, we will explain the variables and methodology, whereas empirical results are discussed in Section 4, which will be followed by conclusion in Section 5 .

3. The absence of abundant research may be because the data on Islamic banks is not available in contrast to that of conventional banks. Furthermore, expertise in this area is limited to few of the researchers, since not everyone has the insight knowledge of how Islamic financial market works.

4. Although Bankscope was also used to obtain and calculate the data but it is highly limited by the number of years and banks. 


\section{REVIEW OF LITERATURE}

The link between CFD and economic growth was first suggested by Schumpeter (1912), who argues that the banks will be responsible for allocating capital to those entrepreneurs who have the ability to come up with innovative ideas and a strategy to successfully implementing them. The allocation will therefore spur growth. This view was later known as "supply leading" or the "Schumpeterian view". The view gained momentum with the publication of work by McKinnon (1973) and Shaw (1973). If we summarize the literature investigating the nexus between CFD and growth, we came across at least three popular views. First, the causality runs from financial development to growth, (for example Patrick, 1966; Jung, 1986; Arestis et al., 2001; King \& Levine, 1993; Levine et al., 2000; Christopoulos \& Tsionas, 2004). Such a view was referred to as supply leading because financial development supplies the stimulus for growth. Second, the causality runs from growth to financial development (for example, Robinson, 1952; Masih \& Masih, 1996). This view was called "demand following", where the financial sector develops in response to increase in demand for financial services. Third, there is a bi-directional causality between financial development and growth, (for example Demetriades \& Hussein, 1996; Blackburn \& Hung, 1998; Luintel \& Khan, 1999; Al-Yousif, 2002).

While Islamic banking performs almost similar functions as that of conventional banking. However, there are many studies attempting to explain how Islamic banking is fundamentally different from the latter. At the same time, there are some studies arguing that the two seems to have only a slight difference and are operationally similar (for more insight into this differentiation, see Kettell, 2011; Hanif et al., 2011; Hanif, 2014; Ayub, 2009). Islamic banks are considered to be in demand where Muslim population is concentrated or in significant proportion. It is because Muslims in general are religiously prohibited not to transact in a contract with interest ${ }^{5}$. For Muslims, it puts a natural ban on conventional banks, which normally deals in interest. It also forces Muslims not to acquire credit from banks or to put their deposit in savings account. Beck et al. (2013) states only $24 \%$ of Muslims were reported to have a bank account in a sample of 64 countries as compared to $44 \%$ of the non-Muslim population. This is referred to as severe under-banking, and the reason can be the presence of interest in conventional banking. In this scenario, there exist a number of potential customers who demand "right" product based on Shariah guidelines, which Islamic banks can tap these customers. The absence of Muslim customers from banks also means that savings are not channeled to productive use, which results in loss of efficiency. In the form of Islamic banking, this group of customers will be provided a platform where they can get more access to finance, as well as to keep their saving in accordance with their religious instructions. This "new" saving will increase the prospects of growth.

The literature on IBD and growth is limited. From this limited literature, there are many theoretical studies and empirical studies are particularly few. Ahmed (2005) was of the view that Islamic banks face certain operational problems

5. There are many forms of "interest" but Interest here mean banking interest.

6. The term Shariah refer to the set of religious principles on which the laws are made. Here we are specifically referring to financial laws. 
related to the use of equity based instruments to finance different projects. He showed that these limitations are causing inefficiencies in the Islamic financial system. If these inefficiencies are removed, then Islamic financial system can play a meaningful role towards growth. His study found that, there is a need to develop Islamic banks further before they can start to play a role in growth. El-Galfy \& Khiyar (2012) theoretically explained that Islamic banking not only contributes to growth, but also helps in macroeconomic stability. In their view, the design of the instruments and the absence of interest help stabilize the economy. Their study further suggested conducting future empirical studies using panel data because it would be more relevant, given the quantity of the data available. Beck et al. (2013) showed that Islamic banks generally have good asset quality, better capitalized, and are more stable even in a financial crisis situation as compared to conventional banks. These particular features of Islamic banks have helped them to cope with the financial crisis of 2008 in a better way as compared to conventional banks. Nagaoka (2010) is another theoretical study examining the link between Islamic banking and growth. His study showed that Islamic finance has the ability to embed the two sectors (financial and real), which then have a greater capability for sustainable growth. On basis of the result, the study concluded that Islamic finance does have the potential of effecting growth because of its close relation with the real sector of the economy. Nedra \& Khoutem (2012) theoretically established that because of the absence of interest, uncertainty (Gharar), speculation and the very nature of instruments used-that are based on profit \& loss, Islamic banking helps in capital accumulation, which positively affects growth. The resulting growth is characterized by more equitable distribution of resources, thereby has the ability to reduce poverty. In addition, they also discuss some policy reforms in Islamic banking before it can start producing positive results.

On empirical side, Mohd. Yusof \& Bahlous (2013) using panel co-integration technique, variance decomposition and impulse response functions, compared Gulf Cooperation Council (GCC) countries and selected Asian countries for a possible effect of Islamic finance on growth. Their results showed this effect to be significant in the long as well as short run. In addition, short run effect was stronger for Indonesia and Malaysia compared to GCC countries. Tajgardoon et al. (2013) also found a positive role of Islamic banking towards growth. Imam \& Kpodar (2016) showed growth is effected positively by IBD. They used pooled regression and generalized Method of Moment (GMM) technique to show positive effects of Islamic banking on growth for a panel of 52 countries, ranging from low to middle income. Kassim (2016) showed positive link between Islamic banking and growth for Malaysia using data from 1998-2004. His study used Autoregressive Distributed Lag model (ARDL) to show that Islamic banking does not cause growth in the short run, but it does in the long run. The same study suggested that Islamic banks should continue promoting Shariah compliant products to attract more customers that will make more funds available for investments.

On the other side, there are studies that either did not find any relationship between Islamic banking and economic growth or at best do not found long term relation. For instance, Hachicha and Amar (2015) used three indicators for Islamic financial development-PRIVATE, which measures the total finance provided by Islamic banks in economy, PRIVIS, that measures the finance provided by the 
Islamic banks to private agents, and finally, INVIS, which measures the contribution of Islamic financial intermediaries in capital accumulation of the economy. Their study used a neoclassical production function augmented by Islamic bank finance for Malaysia for the period 2001 quarter 1 to 2011 quarter 4, concluded no long run relationship between Islamic banking and economic growth. However, they found only short run relationship between Islamic finance and growth. The short run relationship was justified on the ground that Islamic banks in Malaysia engages in non-participatory activities-whose impact is generally short run.

Lebdaoui and Wild (2016) using different estimating techniques like Auto regressive distributed lag (ARDL), Pooled Mean group (PMG), mean group (MG), and dynamic fixed effect (DFE) for selected South Asian countries showed a presence of long run relationship between economic growth and Islamic banking. However, they were unable to conclude any short run relationship between the two. Their results also showed presence of Muslim population was a major factor in the establishment of the positive link between Islamic banking and economic growth. Another justification for the positive role of Islamic banking on growth is the risk limitation imposed by the use of Shariah compliant instruments and their role in mobilizing the savings, which increases the additional resources for the financial sector. On the basis of these results, they recommended governments to facilitate financial deepening by way of promoting Islamic banking products and operation.

Chowdhury et al. (2018) took the case of Islamic banks in Bangladesh and examined the linkage between Islamic financing principles and economic growth. Their study used risk sharing and non-risk sharing modes of Islamic financing principles. They found positive correlation between risk sharing instruments and economic growth while non risk sharing instruments showed negative correlation.

Zirek et al. (2016) using a panel set of 14 countries comprising of members of organization of Islamic cooperation (OIC), showed that an increase in the Islamic financial industry (in the form of deposits, assets and loans) positively affects growth in long run. They found capital stock to be an important indicator of growth. Their study also found that, Islamic finance can be an important factor in attracting foreign investment in to a country. In case of Malaysia, Islamic finance effectively increases the intermediation process by transferring funds from surplus household/units to deficit household/units. Overall they concluded that both in short and long run, Islamic finance seems to affect growth positively.

More recently, Boukhatem and Moussa (2018) analyzed the dynamic role of Islamic finance towards economic growth for selected MENA (Middle East and North Africa) countries. They employed pooled FMOLS (Fully Modified Ordinary Least Square) for the period 2000-2014 and concluded a positive link between Islamic financial development and economic growth. Their study also found a positive role of overall financial deepening to growth. However, as for Islamic financial development, they noted that the positive effect depends on institutional quality. An underdeveloped institutional framework can undermine the positive effect and hence they suggested that developing of Islamic banking should be reinforce with adequate legislation and regulation. Same conclusion was also made by El Mehdi (2017), who studied the relationship for selected 15 countries from MENA region for the period 2000-2009. 
Farahani and Dastan (2013) examined the relation between Islamic finance and economic growth for eight selected countries for the period 2000-2010. Their study also concluded a presence of positive effect of Islamic finance towards growth. Abedifar et al. (2016) took the case of 22 Muslim countries and analyzed the role of Islamic as well as conventional financial system on growth, for the period 1999-2011. Their study concluded a positive link between market share of Islamic banks and economic growth especially in low income and countries and with predominantly Muslim populations. A similar conclusion was also made by a recent study by Lehnert \& Kchouri (2019) for the relation between Islamic banking development and economic growth for 32 countries ranging from developed to developing countries.

\section{METHODOLOGY}

\subsection{Variables and Data sources}

The data on Islamic banking variables were limited because of two main reasons. First, there is limited data available on Islamic banking variables. Second, many non-Islamic banks have Islamic bank operations and windows, but they do not present the data on Islamic banking separately. For this reason, this study calculates most of the data from the financial statements of Islamic banks. This makes the panel more balanced, unlike the case if the data was taken form an existing database on Islamic banks ${ }^{7}$. It will also increase the number of observations and number of banks in data. In addition, unlike the case of other studies, the current study calculated two measures of IBD-Islamic Bank Gross financing (IBGL), which is the total finance provided by Islamic banks to private and non-private sectors. This measure will try to capture the size of the Islamic banks. The second measure is Islamic Bank Total Assets (IBTA), which capture the efficiency of Islamic banks. The dependent variable in our regression will be GDP per capita (growth).

Our study also uses the CFD measure and use them alternatively along with dependent variable. It is because almost all countries included in the sample, where there is Islamic banking there is also a strong presence of conventional banking. Therefore, to capture the effect of the conventional banking on growth, this study will use Domestic Credit by conventional banks (DC), as a measure of CFD. DC is a standard measure of CFD and has been used extensively in literature (See Beck et al., 2000; Beck et al., 2000; 2010; Levine, 2005; Beck et al., 2008). The use of CFD may help to isolate the effect of IBD on growth and to analyze effect of CFD on growth in the presence of Islamic banking (for more information see Levine, 1997; Levine et al., 2000). Other variables that are used as control variables include, Government Consumption (GCons), foreign direct investment (FDI), inflation (Inf), trade openness (TO), and quality of institutions (INS). Acemoglu et al. (2003) showed that INS does matter for long term growth. Our study will use

7. This study acknowledges the use of Bank-scope, but the data was limited and not balanced. Furthermore, there is a limited number of banks and some banks have not been updated since long. To calculate the missing figures and update the data with new banks and more number of years, the financial statements were used. This attempt to balance the data and to update was not tried before according to our knowledge. 
contract enforcement as a broad measure of quality of institutions. It is more likely that if contracts were enforced in a country, the INS would be better, which in turn will promote growth. Annual data on 24 countries covering period from 20042014 is used for the study. The choice of countries and time period is based on the availability of data. Moreover, the selection of countries is based on the principle that data on Islamic banking is available for the period considered. Unlike other studies, the current study is based on a balanced panel that will reduce the number of unobserved observations or skipped values. Names of countries included in the panel and data sources, see Appendix.

\subsection{Empirical Methodology}

The present study divides the estimation procedure into three steps. The first step will try to assess the impact of IBD on growth, while in second step, we will try to determine the presence of a long run relationship between IBD and growth. If a long run relationship exists then, in the third and last step we will try to examine the direction of causality between the two.

\subsubsection{Panel Fixed Effect}

The basic equation for fixed effect can be written as,

$$
Y_{i t}=\alpha_{i t}+\beta_{i} X_{i t}+\mu_{i t}
$$

Where, $\alpha_{i t}$ is the unknown intercept for each country in sample, $Y_{i t}$ is the dependent variable (GDP per capita growth or growth), $\mu_{i t}$ is the error term and $X_{i t}$ is a vector of control variables that include,

$$
X_{i t}=(I B D, F D I, T O, I N S, I N F, G C o n s, C F D)
$$

IBD is Islamic banking proxy variable and CFD is conventional financial development proxy. The subscript $i(=1,2, \ldots . n)$ represents country and $t(=1,2, \ldots . . T)$ the period of times in year.

\subsubsection{Panel Co-Integration Test}

The method developed by Pedroni et al. (1999) and Pedroni (2004), Johansen Fischer (Maddala \& Wu,1999) and Kao (1999) will be used to test the long run relation among the variables. The Pedroni and Kao test are based on Engle \& Granger (1987) approach, whereas Fischer test is a combination of Johansen \& Juselius (1990) tests.

Pedroni offered seven test statistic to measure co-integration among the variables. An advantage of using Pedroni is that it allows heterogeneity across the cross sectional units of panel. Among seven statistic, four panel statistic(panel , panel, panel PP and panel ADF) are based on pooling the residuals of regression along within dimension of panel and the rest of them (group, group PP and group ADF statistic) are based on pooling the residuals of regression along between 
dimensions of panel. The basic idea is, for each member of the panel, to estimate integrating relationship. After estimating it will then pool the residuals to conduct the panel tests ${ }^{8}$.

An empirical form of the Pedroni test can be depicted as,

$$
Y_{i t}=\alpha_{i t}+\theta_{i t} t+X_{i} \beta_{i}+\epsilon_{i t}
$$

Where $Y_{i t}$ and $X_{i t}$ are the observable variables with order $(Z \times K) \times 1$ and $(Z \times K) \times m$, respectively. In equation $2, \alpha_{i}$ is the intercept and $\theta_{i}$ represent time trend. The $\mathrm{X} i$ are assumed to be I (1). All of the seven statistic are assumed to be distributed normally (asymptotically). The critical values are also calculated and supplied by Pedroni.

Kao (1999) follows the same approach as that of Pedroni. The only exception is that, at first stage, the test specifies the cross sectional specific intercepts and homogeneous coefficients. Therefore, Kao assume heterogeneity in intercept $\alpha_{i}$ and homogeneity in $\beta_{i^{\prime}}$ and $\theta$, which is the time trend and is assumed to be zero.

The third test used is the Johansen Fischer co-integration test (JFC), which is the panel version of the individual Johansen co-integration test. As compared to other tests, JFC test has the advantage of being flexible, simple and appealing for different economic variables. Hanck (2009) declared JFC test to perform well as compared to Pedroni (2004), Kao (1999) and Larsen (2001) co-integration tests based on simulation experiment analysis. The JFC test sums the $p$ values of individual co-integration tests for cross section $i$. More simply, it can be presented as, $-2 \sum_{i=1}^{n} \log \left(\theta_{i}\right)$ where $\theta_{i}$ is the $\mathrm{p}$-value of individual co-integration tests for cross section. The result is presented in the form of chi-square statistic $\left(\chi_{2}^{N} N\right)$. It is important to note here that the lag order is very important to reach at the correct conclusion, and is required so that the residuals are serially uncorrelated and normally distributed. All these co-integration tests will be helpful in explaining the long run relationship among the variables of interest. The use of many tests are based on the fact that many studies dealing with panel data have used one or all of these tests to validate the co-integration among the variables. However, before going for co-integration tests, we will also perform a unit root test, so to have a minimum possibility of spurious results.

\subsubsection{Granger Causality Test}

Co-integration tests establish long run relationship but do not indicate the direction of causality. So Granger Causality test-based on a two-step Engle \& Granger (1987) procedure, augmented with error correction and derived from long run relationship will be applied, to determine the direction of causality. In first step, long run model specified in equation 2 will be estimated and residuals will be gathered. These residuals will then be used to estimate Granger causality with error correction term. To run Granger causality in this manner, a standard vector Error Correction Model (VECM) framework will be used, which take the form?',

8. For more information, see Pedroni et al. (1999).

9. Toda \& Yamamoto (1995) is another method to analyze the causal relation, which is also used in many papers. But this method is used when the variables are of different integrated levels. In our case, all variables are I (1), which is why the selection of VECM was a natural choice. 


$$
\begin{aligned}
\operatorname{srowth}_{i t}= & \alpha_{1 k}+\sum_{l=1}^{m} \varphi 11_{i l} \Delta \text { growth }_{i t-l}+\sum_{l=1}^{m} \varphi 12_{i l} \Delta I B D_{i t-l} \\
& +\delta_{1 i} E C T_{i t-1}+\epsilon_{1 i t}
\end{aligned}
$$

and

$$
\begin{aligned}
\Delta I B D_{i t}=\alpha_{3 k} & +\sum_{l=1}^{m} \varphi 31_{i l} \Delta I B D_{i t-l}+\sum_{l=1}^{m} \varphi 32_{i l} \Delta \text { growth }_{i t-l} \\
& +\delta_{3 i} E C T_{i t-1}+\epsilon_{3 i t}
\end{aligned}
$$

When CFD is introduced in the equations 3 and 4 , then the equations can be written as,

$$
\begin{aligned}
\Delta \text { growth }_{i t}= & \alpha_{2 k}+\sum_{l=1}^{m} \varphi 21_{i l} \Delta \text { growth }_{i t-l}+\sum_{l=1}^{m} \varphi 22_{i l} \Delta I B D_{i t-l} \\
& +\sum_{l=1}^{m} \varphi 23_{i l} \Delta C F D_{i t-l}+\delta_{2 i} E C T_{i t-1}+\epsilon_{2 i t} \\
\Delta I B D_{i t}=\alpha_{4 k} & +\sum_{l=1}^{m} \varphi 41_{i l} \Delta I B D_{i t-l}+\sum_{l=1}^{m} \varphi 42_{i l} \Delta \text { growth }_{i t-l} \\
& +\sum_{l=1}^{m} \varphi 43_{i l} \Delta C F D_{i t-l}+\delta_{4 i} E C T_{i t-1}+\epsilon_{4 i t}
\end{aligned}
$$

and

$$
\begin{gathered}
\Delta C F D_{i t}=\alpha_{5 k}+\sum_{l=1}^{m} \varphi 51_{i l} \Delta C F D_{i t-l}+\sum_{l=1}^{m} \varphi 52_{i l} \Delta_{\text {growth }} \text { it }-l \\
+\sum_{l=1}^{m} \varphi 53_{i l} \Delta I B D_{i t-l}+\delta_{5 i} E C T_{i t-1}+\epsilon_{5 i t}
\end{gathered}
$$

In equations $\Delta$ shows the first difference and $l$ is optimal lag length. $l$ is determined by applying Schwarz Bayesian Criteria (SBC). The model in form can determine the short run and long run causality between two variables. Long run causality can be determined through the error correction term, which is $E C T_{i t}$, which should be theoretically stationary. The error terms in equations $\left(\epsilon_{1 i t} ; \epsilon_{2 i t}\right)$ and so on, follow the usual properties i.e. independent and identically distributed with zero mean and constant variance. Error correction tells the rate of change of adjustment and hence, it is the feedback from long run to short run changes in the dependent variable towards long run equilibrium ${ }^{10}$. To test short run causality, Wald test can be applied on the coefficient of $\operatorname{IBD}\left(\varphi 12_{i l}\right)$ in equation 3 , and growth $\left(\varphi 22_{i l}\right)$ in equation 5 .

10. That is why it is called the error correction term. 
The panel based VECM mentioned allows for two source of causation (one through the lagged dynamic term or short run causality and error correction term or long run causality) and thus three tests of causality tests can be performed. The three tests are (i) short run Granger causality test, (ii) weak exogeneity test, and (iii) strong exogeneity test. The short run Granger causality refers to testing the individual coefficient for a possible causal effect on dependent variable. This causal effect can be determined by measuring the statistical significance of F-statistics based on the null hypotheses $\varphi_{12}=0$ and $\varphi_{32}=0$ for equation (3) and (4) and similar null hypotheses for equation (5), (6) and (7). Masih \& Masih (1996), and Asafu-Adjaye (2000) termed short run causality test as weak test of causality, as the dependent variable responds to short term shocks to the stochastic environment.

On the other side, the weak exogenity test, also called the long run non-causality test, requires non-rejection of null hypothesis $\delta_{1 i}=0$ in case of equation 3 . This is referred to as non-causality running from long run equilibrium deviation in IBD, from the previous period to growth. Similarly, in equation 5 , the weak exogenity test refers to the satisfaction of the null hypotheses $\delta_{2 i}=0$ depicting deviation from long run equilibrium to growth. A similar procedure applies for other equations.

As far as strong causality test is concerned, joint significance of the lagged dynamic terms and ECT can be tested. It is equivalent to test the null hypothesis $\varphi_{22 i l}=\delta_{2 i}=0$ in case of equation (5). This is joint significance test of ECT/IBD. There will be no Granger causality if this null hypothesis is not rejected. On the same lines, Growth does not Granger cause CFD if $\varphi_{52 i l}=\delta_{5 i}=0$ (ECT/Growth) cannot be rejected in equation (7). Similar reasoning can be applied for other equations. This is termed as the strong Granger causality test as mentioned in Mahadevan \& Asafu-Adjaye (2007), Yoo (2006) and Mehrara (2007). This test help indicates the variables active to short term adjustment and to re-establish long run equilibrium after a shock to the system.

\section{ESTIMATION RESULTS}

This section will present results in four steps. The first step will present results for panel fixed effects. The second will report the stationarity of the variables through unit root tests, while the third will examine the co-integration among the variable. Finally, the long and short run causality tests are discussed in fourth step.

\subsection{Panel Fixed Effect Results}

Table 1 presents the result for panel fixed regressions. In all of these regressions (column 1-4) the dependent variable is growth. In column 1 and 3, growth is regressed on IBD proxy along with other economic variables to see its effect. In column (2 and 4) growth is regressed on IBD proxies, along with CFD proxy. In all of the regressions, IBD proxy show positive effect on growth. The coefficient of IBD in all regressions is positive and significant at 5\% level of significance. This finding confirms the famous view on the relationship between finance and growth for Islamic banking. The result is true even in the presence of CFD. More precisely, for a given level of financial development, Islamic banking seem to effect growth as the coefficients are positive and significant in both estimations. Apart from IBD, 
CFD is also positively effecting growth in all the equations, validating the classic link between CFD and growth. It can be concluded from the results that IBD, apart from conventional finance, have its own impact on growth. Because most of countries in the data set are Muslim and have both Islamic and conventional financial institutions, so for the time being, Islamic banking does not seem to crowd out conventional banks, perhaps strengthening overall financial market by offering extended and substitute products in financial market in general. Similarly, a positive and significant IBD coefficient also means that Islamic banking is responding and fulfilling the demand for those customers who do not wish to transact in interest or they want substitute products along with conventional financial instruments. The coefficient of IBD in all estimation results are relatively small as compared to CFD, but significant. Our results for IBD closely matches with the results of Zirek et al. (2016). For example, in 1, if Islamic banking gross loans increase by $10 \%$, it will increase growth by $0.072 \%$. This increase is significant at $1 \%$ level, which is positive indication for IBD's role on growth.

As for other variables in equation 1, government consumption expenditure is positively and significantly affecting growth. The same is true for trade openness (except for column 3). However foreign direct investment is negative and significant which is not a surprising result given the fact that developing countries have problem of weak policies, less trained human capital and institutions as shown by Haddad \& Harrison (1993), Carkovic \& Levine (2002) and Borensztein et al. (1998). Trade openness seems to effect growth positively, which is contrary to recent literature that shows a negative effect of liberalization on economic growth. Thus, our findings for trade openness are in confirmation with Karam et al. (2015) who showed a positive effect of trade openness and growth for MENA region.

In addition, most of the countries have not well developed financial system (although it's on an evolving stage now) so, investment is not fully utilized. The finding on FDI is also suggestive for why the quality of institutions have not been significant as well. Inflation is having the usual negative sign. Usual in the sense that macroeconomic theories differ in their views about inflation-growth nexus. Classical and neo-classical theories do not recognize the relationship in short term but agree to a negative long-term relationship. On the other side, Keynesian and neo-Keynesians believed both of them to be independent in short run and for long run, to be positively dependent. Our result of negative relationship can be explained by high inflation that some of the panel countries may have during the period under study.

Approximately similar results are true for all the regressions, where IBD and CFD are affecting the growth positively, since the coefficient of both is positive in all regressions and significant. The coefficient of GCons is also positive and significant. On the other hand, FDI is negative all over and effecting growth significantly. The quality of institutions is positive in all of these results but it is insignificant. The diagnostic tests are within normal ranges and shows that almost 60 to 68 percent of the variability in growth is explained by the explanatory variables. Our results relating to Islamic financial development and conventional finance to growth are in accordance with Imam and Kpodar (2016) and Boukhatem and Moussa (2018), who showed that Islamic finance have positive effect on growth even if we control for conventional finance. 
Table 1.

The Islamic Banking \& Economic Growth: Panel Fixed Effect Regression

\begin{tabular}{lllll}
\hline Variable & $\mathbf{( 1 )}$ & $\mathbf{( 2 )}$ & $\mathbf{( 3 )}$ & $\mathbf{( 4 )}$ \\
\hline const & $2.6868^{* * *}$ & $2.6452^{* * *}$ & $2.6869^{* * *}$ & $2.6452^{* * *}$ \\
& $(0.0000)$ & $(0.0000)$ & $(0.0000)$ & $(0.0000)$ \\
IBGL & $0.00722^{* *}$ & $0.00616^{* *}$ & & \\
IBTA & $(0.0302)$ & $(0.0455)$ & & \\
& & & $0.00513^{* *}$ & $0.00441^{* *}$ \\
FDI & & & $(0.0372)$ & $(0.0529)$ \\
& $-0.00686^{* * *}$ & $-0.0072^{* * *}$ & $-0.0068^{* * *}$ & $-0.0073^{* * *}$ \\
G. Cons & $(0.0001)$ & $(0.0000)$ & $(0.0001)$ & $(0.0000)$ \\
& $0.04353^{* * *}$ & $0.06235^{* * *}$ & $0.04349^{* * *}$ & $0.06239^{* * *}$ \\
INS & $(0.0064)$ & $(0.0001)$ & $(0.0065)$ & $(0.0001)$ \\
& 0.27208 & 0.200594 & 0.27291 & 0.200609 \\
TO & $(0.1408)$ & $(0.2482)$ & $(0.1401)$ & $(0.2488)$ \\
& $0.02125^{* * *}$ & $0.02101^{* * *}$ & $-0.02124^{* * *}$ & $0.02101^{* * *}$ \\
INF & $(0.0015)$ & $(0.0010)$ & $(0.0015)$ & $(0.0010)$ \\
& $-0.00871^{* *}$ & $-0.008912^{* *}$ & $-0.00873^{* *}$ & $-0.00894^{* *}$ \\
DC & $(0.0528)$ & $(0.0346)$ & $(0.0523)$ & $(0.0343)$ \\
& & $0.013550^{* * *}$ & & $0.01358^{* * *}$ \\
\hline
\end{tabular}

Notes: ${ }^{*},{ }^{* *},{ }^{* * *}$ indicate significance at $10 \%, 5 \%$ and $1 \%$ level of significance. Figures in brackets are the p-values

\subsection{Results of Panel Unit Root}

In table 2 we present the results of unit root. For all three variables (growth, IBD proxies and CFD) the null hypothesis of a unit root cannot be rejected at first difference. At level, only Levin, Lu and Chu test shows variables to be stationary. For all other tests, the null hypothesis cannot be rejected. IBGL is only weakly stationary in ADF tests, whereas IBTA and DC are stationary at level according to PP Fisher test. Since Levin, Lu and Chu test has lower power than the other tests ${ }^{11}$, making it reasonable to conclude that all variables are non-stationary at levels. In other words, it can be concluded that they are integrated of order one or I (1), which mean after taking the difference, all series become stationary. To summarize the result of panel unit root tests, all the series have unit root across countries. Based on these results we can expect the series to be co-integrated and thus we can proceed for the co-integration test.

\subsection{Panel Co-Integration Tests Results}

After establishing I (1) for all variables, the co-integration test can be performed to assess the presence of long run relationship. The results are given in Table (3-6), which are in two steps. Table 3 and 4 present results for co-integration between growth and IBD proxies, whereas table 5 and 6 presents the same for growth and IBD proxies including the CFD proxy. 
Table 2.

Results of Panel Unit Root Tests

\begin{tabular}{lcccccc}
\hline Test & \multicolumn{2}{c}{ Levin, Lin \& Chu test } & \multicolumn{2}{c}{ Breitung test } & \multicolumn{2}{c}{ Im Pesaran \&Shin } \\
\hline Varb & Level & 1st Diff & Level & 1st Diff & Level & 1st Diff \\
\hline Growth & $-5.8145^{* * *}$ & $-12.460^{* * *}$ & 2.8687 & $-6.5709^{* * *}$ & 1.4186 & $-1.922^{* *}$ \\
& $(0.0000)$ & $(0.0000)$ & $(0.9979)$ & $(0.0000)$ & $(0.9979)$ & $(0.0273)$ \\
IBTA & $-1.6374^{* *}$ & $-12.992^{* * *}$ & 8.7953 & $-3.0144^{* * *}$ & 0.4921 & $-2.2045^{* * *}$ \\
& $(0.0508)$ & $(0.0000)$ & $(0.9953)$ & $(0.0013)$ & $(0.6887)$ & $(0.01370)$ \\
IBGL & $-4.3702^{* * *}$ & $-13.5938^{* * *}$ & 6.9694 & $-4.7143^{* * *}$ & -0.3786 & $-3.3868^{* * *}$ \\
& $(0.0000)$ & $(0.0000)$ & $(1.0000)$ & $(0.0000)$ & $(0.35250)$ & $(0.0004)$ \\
DC & $-6.004^{* * *}$ & $-10.2707^{* * *}$ & 2.9772 & $-1.9558^{* *}$ & -0.2541 & $-1.7602^{* *}$ \\
& $(0.0000)$ & $(0.00000)$ & $(0.9985)$ & $(0.0252)$ & $(0.3997)$ & $(0.0392)$ \\
\hline
\end{tabular}

Notes: Lag length are selected on AIC criteria. ${ }^{*},{ }^{* *},{ }^{* * *}$ indicate significance at $10 \%, 5 \%$ and $1 \%$ level of significance. Figures in brackets are the p-values

\begin{tabular}{lcccc}
\hline & \multicolumn{2}{c}{ ADF Fischer test } & \multicolumn{2}{c}{ PP Fisher test } \\
\hline Varb & Level & 1st Diff & Level & 1st Diff \\
\hline Growth & 37.4971 & $86.0189^{* * *}$ & 41.0530 & $166.87^{* * *}$ \\
& $(0.8627)$ & $(0.0006)$ & $(0.7510)$ & $(0.0000)$ \\
IBTA & 50.2625 & $99.037^{* * *}$ & $80.4440^{* * *}$ & $145.85^{* * *}$ \\
& $(0.3839)$ & $(0.0000)$ & $(0.0023)$ & $(0.0000)$ \\
IBGL & $61.7724^{*}$ & $116.49^{* * *}$ & 57.0926 & $168.93^{* * *}$ \\
& $(0.0874)$ & $(0.0000)$ & $(0.1730)$ & $(0.0000)$ \\
DC & 52.1962 & $86.2835^{* * *}$ & $66.507^{* *}$ & $124.764^{* * *}$ \\
& $(0.3142)$ & $(0.0006)$ & $(0.03960)$ & $(0.0000)$ \\
\hline
\end{tabular}

Notes: Lag length are selected on AIC criteria. ${ }^{*}, * *,{ }^{* * *}$ indicate significance at $10 \%, 5 \%$ and $1 \%$ level of significance. Figures in brackets are the p-values

The Johansen-Fisher test in table 3 shows the null hypothesis of no co-integration can be rejected at the $1 \%$ level of significance, which is a strong result for a long run relationship. Same is true for the three variable case in Table 6 . The variables are significant at $1 \%$ level of significance, which shows presence of long run relationship among the three variables. In both tables ( 3 and 6$)$, the trace value and maximum Eigen value shows presence of at least one co-integrated vector. Table 3 and 6 also shows the long run co-integration for different proxies of IBD and CFD respectively. The result shows that, Johansen-Fischer test support existence of cointegration among the variables. The result of Pedroni test are presented in table 4 for growth and IBD. It shows that five out of seven test statistics reject the null hypothesis of no co-integration at $1 \%$ and $5 \%$ level of significance. Hence, Pedroni test conclude that there exists a long run relationship among the variables. If we compare the results of Pedroni in table 4, with results in table 5 - which shows the co-integration results among the same growth and IBD proxy with the addition of CFD proxy, it can be seen that four out of seven test statistics shows the presence of co-integration among the three variables. The three tests that do not reject the null hypothesis (Panel -statistic, Panel -statistic and Group -statistic) can have a very low power in the small time dimension as noted by Pedroni, which may render them not to detect co-integration. The same was also mentioned by Al-Iriani (2006). 
In summary, on the basis of results from Pedroni test, it can be concluded that there exists co-integration among the variables for both tables. The result of Kao test with intercept and no trend is presented in bottom panel of table 4 . According to results, it also rejects the null hypotheses of no-co-integration at $1 \%$ level of significance for all cases. Whereas, only in bottom panel of table 5, it shows the presence of co-integration at 5\% level of significance. The acceptance of alternative hypothesis according to Kao-ADF test statistic also lead to conclusion that there exists a long run relation among growth-IBD and Growth, IBD and CFD. On the basis of all the tests, it can be concluded that there exists a long run relationship among the growth, IBD. This would still be true if CFD is included in the model. The use of so many tests and their conclusion may also rule out the estimated relationship among variables to be spurious.

Our results corroborate to that of Lebdaoui and Wild (2016) for South East Asia, Shabri et al. (2015) for Malaysia and Farahani and Dastan (2013) for selected ten countries. The studies showed presence of long run relation between Islamic banking and economic growth.

Table 3.

Panel Co-integration Tests: Johansen Fischer Co-integration Test-Unrestricted Co-integration Rank Test (Trace \& Maximum Eigen Values)

\begin{tabular}{lcccc}
\hline Series Prob. & No of CE & Trace Value & Prob. & Max-Eigen Value \\
\hline Growth, IBGL & None & $167.9^{* * *}$ & 0.0000 & $138.0^{* * *}$ \\
0.0000 & At most1 & $109.3^{* * *}$ & 0.0000 & $109.3^{* * *}$ \\
0.0000 & None & $215.6^{* * *}$ & 0.0000 & $170.1^{* * *}$ \\
$\begin{array}{l}\text { Growth, IBTA } \\
0.0000\end{array}$ & At most 1 & $133.3^{* * *}$ & 0.0000 & $133.3^{* * *}$ \\
0
\end{tabular}

Probabilities are computed using the asymptotic Chi-square distribution. ${ }^{*}, * *, * * *$ indicate significance at $10 \%, 5 \%$ and $1 \%$ level of significance.

Table 4.

Pedroni \& Kao Panel Co-integration Tests Results for Growth and IBD

\begin{tabular}{lcc}
\hline & $\begin{array}{c}\text { Growth, IBGl } \\
\text { Statistic }\end{array}$ & $\begin{array}{c}\text { Growth, IBTA } \\
\text { Statistic }\end{array}$ \\
\hline Pedroni test & & \\
Within Dimension & & \\
Panel $\vartheta$-statistic & 0.7685 & 0.8376 \\
Panel $\rho$-statistic & $-3.7361^{* *}$ & $-3.6053^{* *}$ \\
Panel PP-statistic & $-13.1130^{* * *}$ & $-13.0194^{* * *}$ \\
Panel ADF-statistic & $-14.0125^{* * *}$ & $-13.2871^{* * *}$ \\
Between dimension & & \\
Group $\rho$-statistic & 0.4940 & 0.6644 \\
Group PP-statistic & $-10.0612^{* * *}$ & $-9.2812^{* * *}$ \\
Group ADF-statistic & $-10.4663^{*}$ & $-9.1594^{*}$ \\
Kao test & & \\
ADF & $-3.2104^{* * *}$ & $-11.1277^{* * *}$ \\
Prob. & $(0.0007)$ & $(0.0000)$ \\
\hline$* * * * *$ indicate significance at $10^{*} \%, 5 \%$ and $1 \%$ level of significance. &
\end{tabular}

****** indicate significance at $10 \%, 5 \%$ and $1 \%$ level of significance. 
Table 5.

Pedroni \& Kao Panel Co-integration Tests Results for Growth, IBD and CFD

\begin{tabular}{lcc}
\hline & $\begin{array}{c}\text { Growth, IBGL,DC } \\
\text { Statistic }\end{array}$ & $\begin{array}{c}\text { Growth, IBTA,DC } \\
\text { Statistic }\end{array}$ \\
\hline Pedroni test & & \\
Within Dimension. & -16.937 & -15.438 \\
Panel $\vartheta$-statistic & 22.082 & 18.898 \\
Panel $\rho$-statistic & $-1.5479^{* *}$ & $-2.491^{* *}$ \\
Panel PP-statistic & $-1.7803^{* * *}$ & $-3.4106^{* * *}$ \\
Panel ADF-statistic & & \\
Between dimension & 40.075 & 38.762 \\
Group $\rho$-statistic & $-1.9754^{* *}$ & $-3.9316^{* * *}$ \\
Group PP-statistic & $-2.7610^{* * *}$ & $-5.5730^{* * *}$ \\
Group ADF-statistic & & \\
Kao test & $-1.8563^{* *}$ & $-1.8823^{* *}$ \\
ADF & $(0.0317)$ & $(0.0299)$ \\
Prob. &
\end{tabular}

Table 6.

Panel Co-integration Tests: Johansen Fischer Co-integration Test-Unrestricted Co-integration Rank Test (Trace \& Maximum Eigen Values)

\begin{tabular}{lrcccc}
\hline Series & No of CE & Trace Value & Prob. & Max-Eigen Value & Prob. \\
\hline Growth, IBGL,DC & None & $202.2^{* * *}$ & $(0.0000)$ & $202.2^{* * *}$ & $(0.0000)$ \\
& At most 1 & $296.2^{* * *}$ & $(0.0000)$ & $236.3^{* * *}$ & $(0.0000)$ \\
& At most 2 & $158.6^{* * *}$ & $(0.0000)$ & $158.6^{* * *}$ & $(0.0000)$ \\
Growth, IBTA,DC & & & & & \\
& None & $270.4^{* * *}$ & $(0.0000)$ & $270.4^{* * *}$ & $(0.0000)$ \\
& At most 1 & $282.5^{* * *}$ & $(0.0000)$ & $238.4^{* * *}$ & $(0.0000)$ \\
& At most 2 & $136.1^{* * *}$ & $(0.0000)$ & $136.1^{* * *}$ & $(0.0000)$ \\
\hline
\end{tabular}

Probabilities are computed using the asymptotic Chi-square distribution. ${ }^{*}, * * * * *$ indicate significance at $10 \%, 5 \%$ and $1 \%$ level of significance.

\subsection{Causality Results}

Given the presence of a long run relation between IBD and growth, and between IBD, CFD and growth, the next step would be using Granger causality test to test the direction of causality. Table 7 shows the results from the test for IBD and growth, and table 8 for IBD, growth and CFD.

Table 7 present the results for the Granger causality test based on equation 3 and 4. Panel an of table 7 use the first proxy of IBD-IBGL. Table $7 \mathrm{~b}$ uses the second proxy IBTA. If we look at the short run results for all the tables mentioned, which are given in the form of the Wald test for coefficient restriction, it suggests that there is a short run causality running from IBD to growth for all cases. In table $7 \mathrm{a}$, the coefficient is significant at $1 \%$ level of significance while in table $7 \mathrm{~b}$ the coefficient is significant at $5 \%$ level of significance. When the same tables (7a) and (7b) are analyzed for reverse causality, i.e. from growth to IBD, we did not find any short run causality between the two. 
The coefficient of ECT term, however, shows a different picture. If we look at all the results, we can see that it is significant in all cases where the dependent variable is growth. For all the other cases, where the dependent variable is IBD, we found no long run causal relationship. The significance of the ECT term shows the dynamic adjustment of the independent variable towards long run equilibrium. In other words, IBD does cause growth in long run. The coefficient of the ECT term also indicates the magnitude of correction in short run equilibrium towards the long run. So for example, in table $7 \mathrm{~b}$ ECT shows in current period the correction factor to be $62 \%$. These results support Zirek et al. (2016), but Zirek only showed this relationship to be true for long run and they did not test the existence of reverse causality, i.e. causality from growth to IBD.

When the Granger causality is checked in the form of equations 5, 6 and 7, the results are even more interesting. The results are presented in table $8(a-b)$. In all of these tables, the short run coefficient of IBD is significant. This means that our results clearly indicate that, there is a causal relation running from IBD to growth. Interestingly, for all short run results, we find this direction of causality to be unidirectional i.e. running from IBD to growth. The long run coefficient or ECT term for both sub tables table 8, where growth is dependent variable, is negative and significant, which show that whenever there is a shock to the system, all variables interact dynamically to restore equilibrium in long run. In other words, IBD and CFD indeed cause growth.

If we analyze the short run results for CFD causing growth, they also point out that in both cases, CFD positively cause growth. In all of these results, there is a one-way causation running from CFD to growth. These short run results prove the supply leading hypothesis, which is well known in literature on financial development. For the long run effect, results also show CFD to effect long run growth. Here, like the short run results, the direction of causality follow supply leading hypothesis-running from financial development to economic growth.

Table 7.

Panel Granger Causality Test

\begin{tabular}{|c|c|c|c|}
\hline \multicolumn{4}{|c|}{$\begin{array}{l}\text { (a) Granger Causality Test (growth \& IBGL) } \\
\text { F-Statistic (Prob.) }\end{array}$} \\
\hline & $\Delta$ growth & $\triangle \mathrm{IBGL}$ & ECT \\
\hline \multirow[t]{2}{*}{$\Delta$ growth } & - & $8.2934^{* * *}$ & $-0.0687^{* * *}$ \\
\hline & - & $(0.0004)$ & (0.0037) \\
\hline \multirow[t]{2}{*}{$\triangle \mathrm{IBGL}$} & 2.5907 & - & 0.6640 \\
\hline & $(0.7778)$ & - & $(0.000)$ \\
\hline
\end{tabular}

(b) Granger Causality Test (growth \& IBTA)

F-Statistic (Prob.)

\begin{tabular}{lrrr}
\hline & $\Delta$ growth & $\Delta$ IBTA & \multicolumn{1}{c}{ ECT } \\
\hline \multirow{2}{*}{ growth } & - & $3.5269^{* *}$ & $-0.6235^{* * *}$ \\
& - & $(0.0314)$ & $(0.0000)$ \\
\multirow{2}{*}{ IBTA } & 0.6132 & - & 0.0045 \\
& $(0.5427)$ & - & $(0.1620)$ \\
\hline
\end{tabular}

Note: ${ }^{*}{ }^{* *}{ }^{* * *}$ shows significant at $10 \%, 5 \%$ and $1 \%$ respectively. Figures in parentheses are the p-values. 
Looking at the joint Wald F-test results, it shows mix evidence for causality between IBD and growth. In table-8(a) the result is supportive of bi-directional causality and in the other 8 (b), for one-way causality. The occurrence of bi-directional causality in case of IBD is not a new phenomenon and many studies are of the view that there may exist a bi-directional causality between finance and growth. Therefore, results of causality test results (strong exogenity test for table $8 \mathrm{~b}$ ) validate the short run results of one-way causality and the direction-running from Islamic banking to economic growth. Results on the significance for the interactive terms of IBD and ECT term on growth suggest that, both in short run and long run, IBD strongly Granger cause growth. It also indicates that in short run, if there is any shock to the system, then Islamic banking and conventional banking variable bears the adjustment to converge to long run equilibrium. On the joint Wald F-test for CFD and ECT term, results show that it is significant in both tables, suggesting causality running from CFD to growth. Our results also show that there is no meaningful relationship between IBD and CFD.

Table 8.

Panel Granger Causality Test

\begin{tabular}{|c|c|c|c|c|c|c|}
\hline \multicolumn{7}{|c|}{$\begin{array}{l}\text { (a) Granger Causality Test (growth, IBGL \& LL) } \\
\text { F-Statistic (Prob.) }\end{array}$} \\
\hline & $\Delta$ growth & $\triangle \mathrm{IBGL}$ & $\Delta \mathrm{DC}$ & ECT (t-statistic) & $\Delta$ growth/ECT & $\Delta \mathrm{IBGL} / \mathrm{ECT}$ \\
\hline \multicolumn{7}{|l|}{$\Delta \mathrm{DC} / \mathrm{ECT}$} \\
\hline$\Delta$ growth & - & $2.7079^{*}$ & $2.0598^{*}$ & $-0.01388^{* *}$ & - & $2.6210^{* *}$ \\
\hline \multicolumn{7}{|l|}{$5.6429^{* *}$} \\
\hline & - & $(0.0694)$ & $(0.0130)$ & $(0.0676)$ & - & $(0.0522)$ \\
\hline \multicolumn{7}{|l|}{$(0.0181)$} \\
\hline$\triangle \mathrm{IBGL}$ & 0.1366 & - & 1.1540 & 0.7246 & $25.8367^{* * *}$ & - \\
\hline \multicolumn{7}{|l|}{$1.1381^{* * *}$} \\
\hline \multicolumn{7}{|l|}{$(0.1813)$} \\
\hline \multirow[t]{2}{*}{$\Delta \mathrm{DC}$} & 0.0708 & 0.1265 & - & & 0.9522 & 1.4206 \\
\hline & $(0.9316)$ & $(0.8812)$ & - & $\begin{array}{r}-0.0016 \\
(0.1130)\end{array}$ & $(0.4166)$ & \\
\hline \multicolumn{7}{|c|}{$\begin{array}{l}\text { (b) Granger Causality Test (growth, IBTA\& DC) } \\
\text { F-Statistic (Prob.) }\end{array}$} \\
\hline & $\Delta$ growth & $\Delta$ IBTA & $\Delta \mathrm{DC}$ & ECT (t-statistic) & $\Delta$ growth/ECT & $\triangle \mathrm{IBTA} / \mathrm{ECT}$ \\
\hline \multicolumn{7}{|l|}{$\triangle \mathrm{DC} / \mathrm{ECT}$} \\
\hline $\begin{array}{l}\Delta \text { growth } \\
6.6279^{* * *}\end{array}$ & - & $3.8166^{* * *}$ & $2.1613^{* *}$ & $-0.5913^{* * *}$ & - & $7.0677^{* * *}$ \\
\hline & - & $(0.0058)$ & $(0.0729)$ & $(0.0000)$ & - & $(0.0000)$ \\
\hline$(0.0000)$ & & & & & & \\
\hline$\triangle \mathrm{IBTA}$ & 1.2892 & - & $2.0078^{*}$ & -0.0296 & 1.0387 & - \\
\hline 1.7023 & $(0.2775)$ & - & $(0.0972)$ & $(0.5672)$ & $(0.3979)$ & - \\
\hline$(0.1387)$ & & & & & & \\
\hline$\Delta \mathrm{DC}$ & $\begin{array}{r}1.5764 \\
(0.1846)\end{array}$ & $\begin{array}{r}1.6099 \\
(0.2032)\end{array}$ & - & $\begin{array}{r}-0.0010 \\
(0.9059)\end{array}$ & $\begin{array}{l}1.3905 \\
(0.2322)\end{array}$ & $\begin{array}{r}2.9084^{* * * *} \\
(0.1029)\end{array}$ \\
\hline
\end{tabular}

Note: ${ }^{* * *},{ }^{* * *}$ shows significant at $10 \%, 5 \%$ and $1 \%$ respectively. Figures in parentheses are the $\mathrm{p}$-values 
In summary, based on the majority of the results for each case, there exist a long run relationship between IBD and economic growth. In short run, IBD significantly affect growth and the direction of causality is running from IBD to growth. For the long run causality, we found that it is also validating the supply leading hypothesis for IBD. A strong causality is also present between IBD and growth, in one case where the former causes the later. The results unanimously seem to suggest causality from IBD to economic growth. A diagrammatic presentation of the results of table 8 is shows in figure 5. In terms of direction of causality our results confirm the result of Shabri et al. (2015) for Malaysia who also showed unidirectional causality running from Islamic finance to economic growth. However, our result does not support the bi-directional causality as was the case of Farahani and Dastan (2013) and Tajgardoon et al. (2013).

\section{CONCLUSION AND RECOMMENDATION}

\subsection{Conclusion}

This paper had three objectives: (1) analyze the impact of IBD on economic growth, (2) investigate the long run relationship, and (3) find the causal relation between IBD and economic growth. We used data set of panel type, on 24 countries for 11 years to assess the research questions.

\section{Figure 1. \\ Panel Causality Relation Between Growth, Islamic Banking and Conventional Financial Development}
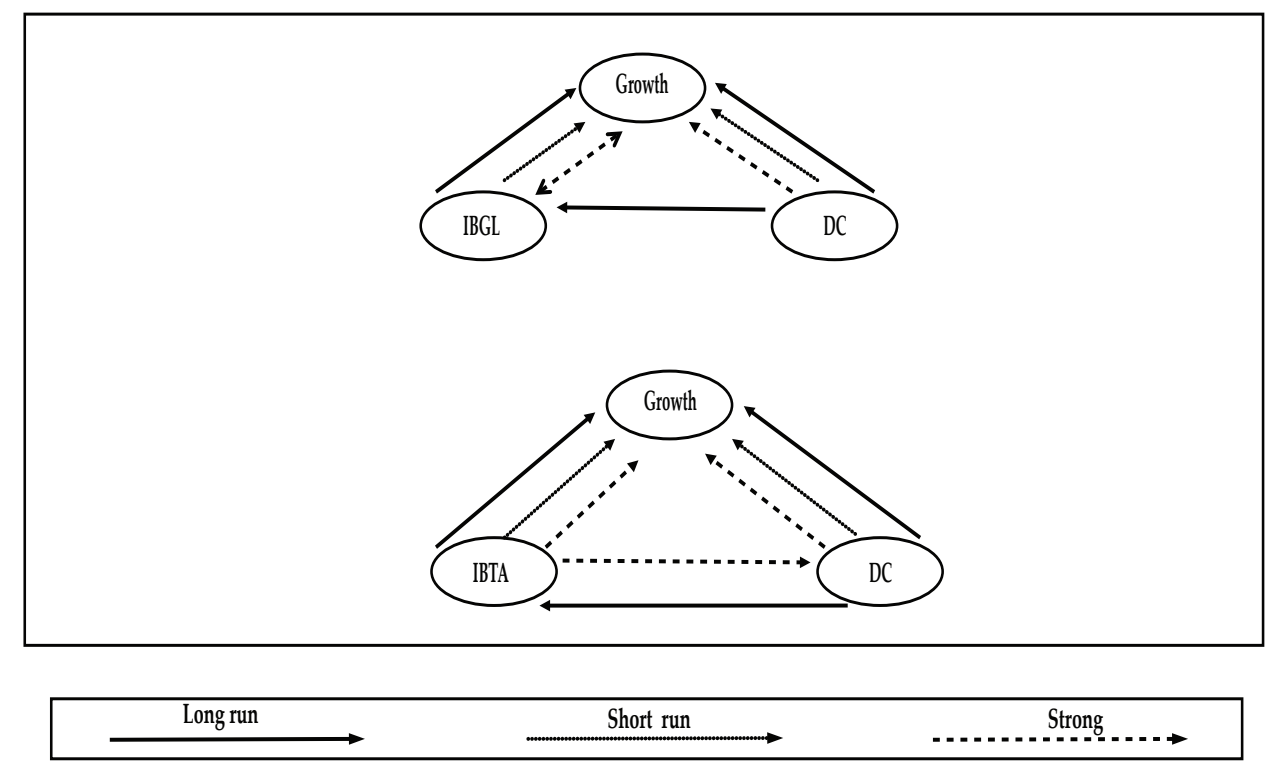

To see the impact, we used panel fixed estimation regression to test the hypothesis. Panel co-integration test were applied to establish the long run relationship between IBD and economic growth, and in combination with CFD. 
After that, an error correction model was used to examine the dynamic relation and causality among the variables. Panel fixed effect estimation shows positive effect of IBD on economic growth. Our study found that holding constant other variables, IBD effects economic growth positively. This is a different result as compared to other research on a similar topic. The positive effect does not disappear even in the presence of CFD as well. We also tried with pooling the data, however the results were not so different ${ }^{12}$. The results are encouraging as Islamic banking is still evolving and has not attained the economies of scale. Moreover, its size to the overall GDP is small for most of the countries. Our study establishes a link between IBD and growth.

Our results are also indicative of a long run relationship between IBD and economic growth. The long run relationship holds for all the proxies that were used to measure IBD and CFD. An interesting result is that results show long run relationship between IBD and Growth. This result does not diminish even when CFD was introduced.

On the direction of causality this is the first paper, to our knowledge, which used balanced data and standard tests to assess the direction of causality between IBD and economic growth. Based on the Granger causality test, our results support causality running from IBD to economic growth. The direction of causality is valid in the long run, as well as for short run. Moreover, the direction of causality seems to be unidirectional i.e. running from IBD to economic growth. On the other hand, we also found CFD to effect economic growth and likewise, the direction seems to follow supply leading hypothesis. Another conclusion that we can draw is that both conventional and Islamic financial systems contribute to economic growth. Our results are supportive of the Schumpeterian view or the supply leading hypothesis. We do not find any convincing relationship between IBD and CFD, which supports the view that Islamic banking, for the time being is not crowding out conventional banking. This result is also unique in the sense that no other study has tested the relation between conventional and Islamic banking in such a causality framework. Thus introduction of another banking system (Islamic banking) with conventional banking has resulted in deepening of the overall financial market, thereby promoting economic growth.

\subsection{Recommendation}

Given the results and the fact that Islamic banking is still evolving and, for the time being, represents a small part of the overall economy and particularly of the financial sector, this study will be helpful in understanding the future role of Islamic financial market and the resources to be put in for its development. Islamic banking has still not believed to gain economies of scale and is still in expansion phase. It is recommended that continuous effort be undertaken to promote Islamic banking. It includes refining legal and regulatory framework as well, that can provide a conducive environment to expand Islamic banking in particular and Islamic financial market in general. Governments may undertake policies that will help facilitate promotion of Islamic banking. This will be especially interesting

12. The result from pooling are not reported 
for non-Islamic countries since our results indicate indirectly that introduction of Islamic banking can help deepening overall financial market and mobilize savings. Given the Muslims prohibition of interest, and the impact of Islamic financial markets on economic growth, it can help to rise saving and bring this to the formal sector. In this context further research for the potential of Islamic banking for nonIslamic countries financial market would be interesting for future research. Last, IBD can improve the growth rate of developing countries since it is believed that it has roots in the real sector of the economy. There is tremendous amount of scope in this field and further research on IBD, especially on the magnitude of its impact on growth and its efficiency, will be able to help formulating policy decisions for the uplift of Islamic banking.

Acknowledgments: The authors are thankful to Dr. George von Wangenheim, Professor Law and Economics, and Dr. Andreas Ghos Department of Statistics, University of Kassel, Germany for providing us with valuable suggestions and constructive comments to improve the paper. Errors and omissions are, of course, our own.

\section{REFERENCES}

Abedifar, P., Hasan, I., \& Tarazai, A. (2016). Finance-Growth Nexus and DualBanking Systems: Relative Importance of Islamic Banks. Journal of Economic Behavior and Organization, 132, 198-215.

Acemoglu, D., Johnson, S., Robinson, J., \& Thaicharoen, Y. (2003). Institutional Causes, Macroeconomics Symptoms: Volatility, Crisis and Growth. Journal of Monetary Economics, 50 (1), 49-123.

Ahmed, H. (2005). The Islamic Financial System and Economic Growth: An Assessment. In Islamic Finance and Economic Development. New York, Palgrave Macmillan. Al-Iriani, M. A. (2006). Energy-GDP Relationship Revisited: An Example from GCC Countries Using Panel Causality. Energy Policy, 34 (17), 3342-3350.

Al-Yousif, Y. K. (2002). Financial Development and Economic Growth: Another Look at the Evidence from Developing Countries. Review of Financial Economics, 11 (2), 131-150.

Arestis, P., Demetriades, P. O., \& Luintel, K. B. (2001). Financial Development and Economic Growth: The Role of Stock Markets. Journal of Money, Credit, and Banking,33(1), 16-41.

Asafu-Adjaye, J. (2000). The Relationship between Energy Consumption, Energy

Prices and Economic Growth: Time Series Evidence from Asian Developing Countries. Energy Economics, 22 (6), 615-625.

Ayub, M. (2009). Understanding Islamic Finance. John Wiley \& Sons limited.

Beck, T., Demirgu_c-Kunt, A., \& Merrouche, O. (2013). Islamic vs. Conventional Banking: Business Model, Efficiency and Stability. Journal of Banking E Finance, 37 (2), 433-447.

Blackburn, K., \& Hung, V. T. (1998). A Theory of Growth, Financial Development and Trade. Economica, 65 (257), 107-124.

Borensztein, E., De Gregorio, J., \& Lee, J.-W. (1998). How Does Foreign Direct Investment Affect Economic Growth? Journal of International Economics, 45 (1), 115-135. 
Boukhatem, J., \& Moussa, F. B (2018). The Effect of Islamic Banks on GDP Growth: Some Evidence from selected MENA Countries. Borsa Istanbul Review, 18(3), 231-247.

Carkovic, M. V., \& Levine, R. (2002). Does Foreign Direct Investment Accelerate Economic Growth? (Working Paper), University of Minnesota.

Chowdhury, M. A. F., Akbar, C. S., \& Shoyeb, M. (2018). Nexus Between Risk Sharing vs Non-Risk Sharing Financing and Economic Growth of Bangladesh: ARDL Bound Testing and Continuous Wavelet Transform (CWT) Approach. Managerial Finance., 44(6), 739-758

Christopoulos, D. K., \& Tsionas, E. G. (2004). Financial Development and Economic Growth: Evidence from Panel Unit Root and Co-integration Test. Journal of Development Economics, 73 (1), 55-74.

Demetriades, P., \& Andrianova, S. (2003). Finance and Growth: What We Know and What We Need To Know. In Financial Development and Economic Growth (3865). Palgrave Macmillan, London.

Demetriades, P. O., \& Hussein, K. A. (1996). Does Financial Development Cause Economic Growth? Time-Series Evidence from 16 Counties. Journal of Development Economics, 51 (2), 387-411.

El-Galfy, A., \& Khiyar, K. A. (2012). Islamic Banking and Economic Growth: A Review. Journal of Applied Business Research, 28 (5), 943.

El Mehdi, I. K., \& Mghaieth, A. (2017). Volatility Spillover and Hedging Strategies between Islamic and Conventional Stocks in the Presence of Asymmetry and Long Memory. Research in International Business and Finance, 39, 595-611.

Engle, R. F., \& Granger, C. W. (1987). Co-integration and Error Correction: Representation, Estimation, and Testing. Econometrica: Journal of the Econometric Society, 251-276.

Ernst, \& Young. (2013). World Islamic Banking Competitiveness Report, 2013-14: the transition begins. Retrieved from http://www.ey.com

Ernst, \& Young. (2015). World Islamic Banking Competitiveness Report, 2014-15. Retrieved from http://www.ey.com

Farahani, Y. G., \& Dastan, M. (2013). Analysis of Islamic Bank's Financing and Economic Growth: A Panel Co-integration Approach. International Journal of Islamic and Middle Eastern Finance and Management, 3(2), 156-172.

Goodhart, C. (2004). Financial Development and Economic Growth: Explaining the Links. Springer.

Hachicha, N., \& Ben Amar, A. (2015). Does Islamic Bank Financing Contribute to Economic Growth? The Malaysian Case. International Journal of Islamic and Middle Eastern Finance and Management, 8(3), 349-368

Haddad, M., \& Harrison, A. (1993). Are there Positive Spillover from Direct Foreign Investment? Evidence from Panel Data for Morocco. Journal of Development Economics, 42 (1), 51-74.

Hanck, C. (2009). Cross-sectional Correlation Robust Tests for Panel Co-integration. Journal of Applied Statistics, 36 (7), 817-833.

Hanif, M. (2014). Differences and Similarities in Islamic and Conventional Banking. International Journal of Business and Social Science, 2(2). 
Hanif, M., Tariq, M., Tahir, A. (2011). Comparative Performance Study of Conventional and Islamic Banking in Pakistan. International Research Journal of Finance E Economics, (83).

Imam, P., \& Kpodar, K. (2016). Islamic Banking: Good for Growth? Economic Modelling, 59, 387-401.

Johansen, S., \& Juselius, K. (1990). Maximum Likelihood Estimation and Inference on Co-integration with Applications to the Demand for Money. Oxford Bulletin of Economics and statistics, 52 (2), 169-210.

Jung, W. S. (1986). Financial Development and Economic Growth: International Evidence. Economic Development and Cultural Change, 34 (2), 333-346.

Kao, C. (1999). Spurious regression and Residual-Based Test for Co-integration in Panel Data. Journal of Econometrics, 90 (1), 1-44.

Karam, F., Zaki, C., Castel, V., Rad, S., Muhanzu, N., \& Kolster, J. (2015). Du commerce et croissance economique dans la region MENA : Biens ou services ?. In Serie sur les notes de politiques en Afrique du Nord. BAD

Kassim, S. (2016). Islamic Finance and Economic Growth: The Malaysian Experience. Global Finance Journal, 30 , 66-76.

Kettell, B. (2011). Introduction to Islamic Banking and Finance (Vol. 1). John Wiley \& Sons.

King, R. G., \& Levine, R. (1993). Finance, Entrepreneurship and Growth. Journal of Monetary Economics, 32 (3), 513-542.

Larsson,R., Lyhagen,J., and Löthgren, M. (2001). Likelihood-based Co-integration Tests in Heterogeneous Panels, Econometrics Journal, 4, 109-142

Lebdaoui, H. and Wild, J.(2016) “Islamic Banking Presence and Economic Growth in Southeast Asia", International Journal of Islamic and Middle Eastern Finance and Management, 9 (4), 551-569

Lehnert, Thorsten and Kchouri, B. (2019) Islamic Finance and Economic Growth: New Evidence. (Unpublished) paper presented in The 9th International Conference on Economics, 23 Jan to 25 Jan 2019.

Levine, R. (1997). Financial Development and Economic Growth: Views and Agenda. Journal of Economic Literature, 35 (2), 688-726.

Levine, R., Loayza, N., \& Beck, T. (2000). Financial Intermediation and Growth: Causality and Causes. Journal of Monetary Economics, 46 (1), 31-77.

Levine, R.(2003). More on Finance and Growth: More Finance, More Growth? Review-Federal Reserve Bank of Saint Louis, 85 (4), 31-46.

Luintel, K. B., \& Khan, M. (1999). A Quantitative Reassessment of the FinanceGrowth Nexus: Evidence from A Multivariate VAR. Journal of Development Economics, 60 (2), 381-405.

Maddala, G. S., \& Wu, S. (1999). A Comparative Study of Unit Root Tests with Panel Data and a New Simple Test. Oxford Bulletin of Economics and Statistics, 61 (S1), 631-652.

Mahadevan, R., \& Asafu-Adjaye, J. (2007). Energy Consumption, Economic Growth, and Proces: A Reassessment using Panel VECM for Developed and Developing Countries. Energy Policy, 35 (4), 2481-2490.

Masih, R., \& Masih, A. M. (1996). Macroeconomic Activity Dynamics and Granger Causality: New Evidence from a Small Developing Economy based on Vector Error-Correction Modeling Analysis. Economic Modeling, 13 (3), 407-426. 
McKinnon, R. (1973). Money and Capital in Economic Development (Brookings, Washington, DC).

Mehrara, M. (2007). Energy Consumption and Economic Growth: The Case of Oil Exporting Countries. Energy Policy, 35 (5), 2939-2945.

Mohd. Yusof, R., \& Bahlous, M. (2013). Islamic Banking and Economic Growth in GCC \& East Asia Countries: A Panel Co-integration Analysis. Journal of Islamic Accounting and Business Research, 4 (2), 151-172.

Nagaoka, S. (2010). Islamic Finance in Economic History: Marginal System or another Universal System? In Second Workshop on Islamic Finance: What Islamic Finance Does (not) Change? European Research Group Jointly with Em Strasbourg Business School, Large Research Center and Institute de Finance de Strasbourg, France.

Nedra, B. A., \& Khoutem, B. J. (2012). Islamic Participative Financial Intermediation and Economic Growth. Journal of Islamic Economics, Banking and Finance, 8 (3), 44-59.

Patrick, H. T. (1966). Financial Development and Economic Growth in Underdeveloped Countries. Economic Development and Cultural Change, 14 (2), 174-189.

Pedroni, P. (2004). Panel Co-integration: Asymptotic and Finite Sample Properties of Pooled Time Series Tests with an Application to the PPP Hypothesis. Econometric Theory, 20 (3), 597-625.

Pedroni, P., et al. (1999). Critical Values for Co-Integration Tests in Heterogeneous Panels with Multiple Regressors. Oxford Bulletin of Economics and Statistics, 61 (1), 653-670.

Robinson, J. (1952). The Generalization of the General Theory, in the Rate of Interest and Other Essays (MacMillan, London).

Schumpeter, J. A. (1912). The theory of Economic Development. Cambridge, MA: Harvard University Press.

Shabri, M., Majid, A. and Kassim, S.H. (2015), Assessing The Contribution of Islamic Finance to Economic Growth: Empirical Evidence from Malaysia", Journal of Islamic Accounting and Business Research, 6(2), 292-310.

Shaw, E. S. (1973). Financial Deepening in Economic Development. Oxford University Press.

Tajgardoon, G., Behname, M., \& Noormohamadi, K. (2013). Islamic Banking and Economic Growth: Evidence from Asia. Journal of Modern Accounting and Auditing, 9 (4), 542.

Toda, H. Y., \& Yamamoto, T. (1995). Statistical Inference in Vector Auto-regressions with Possibly Integrated Processes. Journal of Econometrics, 66(1-2), 225-250.

Yoo, S. (2006). The Causal Relationship between Electricity Consumption and Economic Growth in ASEAN Countries Energy Policy, 34, 3573-3582.

Zirek, D., Celebi, F., \& Hassan, M. K. (2016). The Islamic Banking and Economic Growth Nexus: A Panel VAR Analysis for Organization of Islamic Cooperation (OIC) Countries. Journal of Economic Cooperation E Development, 37 (1), 69. 


\section{A.1. Appendix.}

\begin{tabular}{ccclclcl} 
A.1. Name of Countries & \multicolumn{1}{l}{. } & Same of \\
Sr. No & $\begin{array}{c}\text { Country } \\
\text { Sr. No }\end{array}$ & $\begin{array}{c}\text { Name of } \\
\text { Country }\end{array}$ & Sr. No & $\begin{array}{c}\text { Name of } \\
\text { Country }\end{array}$ & Sr. No & $\begin{array}{c}\text { Name of } \\
\text { Country }\end{array}$ \\
\hline 1 & Bahrain & 7 & Kenya & 13 & Pakistan & 19 & Sudan \\
2 & Bangladesh & 8 & Kuwait & 14 & Philippines & 20 & Thailand \\
3 & Egypt & 9 & Lebanon & 15 & Qatar & 21 & Tunisia \\
4 & Indonesia & 10 & Malaysia & 16 & Saudi Arabia & 22 & Turkey \\
5 & Iran & 11 & Mauritania & 17 & Singapore & 23 & UEA \\
6 & Jordan & 12 & Morocco & 18 & South Africa & 24 & Yemen \\
\hline
\end{tabular}

\section{A.2. Data Sources}

\begin{tabular}{ll}
\hline Name of Series & \multicolumn{1}{c}{ Source } \\
\hline 1 Islamic Bank Gross loans & Financial Statements (Author Own calculations) \\
2 Islamic Bank Total Assets & Financial Statements (Author Own calculations) \\
3 Foreign Direct Investment & World Development Indicators, World Bank \\
4 Government Consumption & World Development Indicators, World Bank \\
5 Institutions & World Wide Governance Indicators. \\
6 Trade Openness & World Development Indicators, World Bank \\
7 Inflation & World Development Indicators, World Bank \\
8 Domestic Credit by Conventional Banks & Global Financial Development, World Bank \\
9 Gross Domestic Product Per capita & World Development Indicators, World Bank \\
\hline
\end{tabular}


This page is intentionally left blank 